\title{
The Practical Aspects of Conscious Attitude Formation to Fatherhood in Conditions of Vocational Educational Institutions
}

\author{
Fediushkina Kateryna \\ ORCID https://orcid.org/0000-0002-2499-5781 \\ Postgraduate student of department of social pedagogics \\ Dragomanov National Pedagogical University (Ukraine, Kyiv)
}

\begin{abstract}
The article presents practical aspects of the formation of a conscious attitude towards paternity among students of vocational schools. The author highlights the reasons for depreciation of the moral and spiritual essence of parenthood in the modern Ukrainian society, contradictions of this problem, which, in fact, determine the relevance of scientific research. The examples of the paternity crisis, in particular, are early pregnancy and motherhood among minors, voluntary abandonment of children, phenomenon of deviant motherhood, as well as voluntary refusal of the birth of children ("Child-free"). The author substantiates the necessity of formation of a conscious attitude towards paternity among the students of vocational and technical institutions, whose age development corresponds to the period of early youth. The article presents the structural-functional model of the process of formation of a conscious attitude towards paternity among students of vocational and technical educational institutions, the components of which are the following - semantic (purpose, task, methodological approaches, principles), informative (program of social and pedagogical support for the formation of a conscious attitude towards paternity "The World of Paternity: from Chaos to Harmony"), operational (forms, methods and means of work), effective (criteria for the formation of a conscious attitude to paternity: epistemological, activity, axiological, acmeological). The practical aspects of formation of a conscious attitude towards paternity in the conditions of vocational and technical educational institutions are revealed; the results achieved by the students are determined.
\end{abstract}

Key words: fatherhood, motherhood, conscious attitude towards fatherhood, students of vocational educational institution.

Актуальність дослідження. Різка зміна пріоритетів, поява нових цінностей та переорієнтація поглядів щодо значимості тих чи інших моральних якостей призводять до занепаду духовної сфери життєдіяльності як суспільства в цілому, так і окремої особистості. Падіння моральних орієнтирів [6], знецінення позитивних духовних відношень між людьми [7; 8] сприяє появі широкого спектру соціальних проблем, які стосуються в першу чергу молодого покоління i, на жаль, дестабілізують його положення у реаліях сучасного світу.

Гострою проблемою українського суспільства наразі є знецінення у

молоді морально-духовної сутності батьківства [1; 2; 5] та формальне виконання батьківських, зокрема і материнських, функцій особами юного віку, чим і обумовлена актуальність нашого дослідження. Викликана вона також і наступними протиріччями: 
- між вимогою суспільної громадськості щодо повноцінного виконання громадянами батьківських обов'язків та відсутністю можливості реалізувати підготовку підростаючого покоління до усвідомленого батьківства соціальними інститутами; - між необхідністю формування усвідомленого ставлення до батьківства у студентів професійно-технічних навчальних закладів та відсутністю теоретичної науково обгрунтованої програми, яка слугувала б підгрунтям для впровадження та реалізації у практику інноваційних форм соціально-педагогічної роботи;

- між ідеалістичним культивуванням суспільною громадськістю значимості батьківства i материнства для дівчини та реальною ситуацією сучасності, яка демонструє першочергове значення досягнення успіхів у кар'єрі, матеріального достатку, престижу, тим самим відсуваючи реалізацію материнської ролі на другий план;

- між бажанням студентів професійно-технічних навчальних закладів демонструвати власну дорослість і незалежність та неготовністю нести відповідальність за власну поведінку та вчинки;

- між прагненням молоді жити задля власного задоволення та необхідністю повноцінно виконувати батьківські обов'язки і піклуватися про власну дитину.

Виклад основного матеріалу. Проявом кризи батьківства на сучасному етапі розвитку суспільства виступає рання вагітність та материнство серед неповнолітніх, добровільна відмова від дітей, явище девіантного материнства, а також добровільна відмова від народження дітей («Child-free»).

У зв'язку з цим зростає необхідність розробки, впровадження та реалізації заходів, спрямованих на відродження цінності батьківства, зокрема й материнства, формування у молоді позитивної мотивації до опанування ролі

батьків, що закладатиме підгрунтя усвідомленого ставлення до батьківства.

Дослідниця Р. Овчарова, розглядаючи батьківство як багатогранний феномен, виокремлює два рівні його прояву - суб'єктивно-особистісний та надіндивідуальний [4, c. 45]. Зазначені рівні виступають й етапами формування батьківства: 1) початковий, тобто суб'єктивно-особистісний, етап пов'язаний 3 формуванням когнітивних, емоційних та поведінкових складових батьківства під впливом макро-, мезофакторів та особистісних характеристик людини, закладається ще до початку сімейного життя та появи дитини; 2) етап надіндивідуального рівня розпочинається з моменту народження 
дитини; проявляється в інтеграції суб'єктивно-особистісних рівнів подружжя, узгодженні їх уявлень про батьківство, а також безпосередня реалізація ролі батька та матері на практиці. Тому, зважаючи на різноманітні прояви кризи у даній сфері, особливої уваги потребує суб'єктивно-особистісний етап формування батьківства у молоді.

Оскільки для раннього юнацького віку характерними особливостями є проблема самовизначення, становлення у цей період ціннісних переконань та системи світоглядних позицій, то важливим, на нашу думку, постає процес формування усвідомленого ставлення до батьківства саме на даному етапі розвитку особистості. Юність є тим періодом, який забезпечує становлення людини як особистості, «коли юнак, перебуваючи на шляху онтогенетичної ідентифікації уподібнення іншим людям, присвоїв від них соціально значущі властивості особистості, здатність до співпереживання, до активного морального відношення до людей, до самого себе і до природи; здатність до засвоєння конвенційних ролей, норм, правил поведінки в суспільстві» [3, с. 422].

У зв’язку з цим нами було розроблено структурно-функціональну модель процесу формування усвідомленого ставлення до батьківства у студентів професійнотехнічних навчальних закладів. Структурними компонентами даної моделі виступають такі:

1. Смисловий: (мета, завдання, методологічні підходи, принципи).

Мета реалізації структурно-функціональної моделі - формування усвідомленого ставлення до батьківства у студентів професійно-технічних навчальних закладів.

Завдання: 1) створити належні умови для формування у студентів ПТНЗ системи теоретичних знань, практичних умінь та навичок, необхідних для ефективної реалізації батьківської ролі у майбутньому; 2) забезпечити розвиток та формування особистісних якостей, які сприятимуть становленню батьківської зрілості студентів ПТНЗ; 3) створити оптимальні умови для формування позитивної мотивації студентів, яка грунтується на усвідомленні місця батьківства у ієрархії цінностей особистості.

Методологічні підходи - діяльнісний, аксіологічний і системний. 
Принщипи реалізації структурно-функціональної моделі включають: принципи педагогічного процесу, принципи соціально-педагогічної діяльності.

2. Змістовний (програма соціально-педагогічної підтримки процесу формування усвідомленого ставлення до батьківства у студентів ПТНЗ «Світ батьківства: від хаосу до гармонії»). Програма включає вступний блок; теоретичний блок, результатом реалізації якого є оволодіння студентами відомостями з педагогіки, вікової психології, психології спілкування, психології сім’ї, фізіології, знань щодо особливостей догляду за дитиною з народження, умов гармонійного ii розвитку, побудови ефективного спілкування тощо; практичний блок, мета якого у формуванні позитивного відношення до себе як до батька/матері, прийняття відповідальності за благополуччя дитини, єдності поглядів батьків щодо виховання дитини, а також оволодінні та закріпленні практичних умінь та навичок щодо процесу розвитку та виховання дитини; блок рефлексії, спрямований на вираження думок та вражень щодо отриманої інформації; заключний блок.

Розроблена модель покликана забезпечити реалізацію наступних функцій: виховну - формування системи поглядів, переконань та ідеалів особистості, необхідних для формування усвідомленого ставлення до батьківства, а також якостей та рис, які забезпечать успішну реалізації батьківського потенціалу; розвивальну супроводжується своєрідними змінами у розумінні студентами сутності батьківства, його призначення, у якісно новому відношенні до даного феномену; соціалізуючу полягає у засвоєнні та поступовому відтворенні студентами ПТНЗ загальнолюдського досвіду, пов'язаного з багатовіковими традиціями сприймання батьківської ролі та виховання дітей; мотиващійну - спрямована на формування у студентів позитивної мотивації до реалізації батьківства; інформаційну - полягає у збагаченні інтелектуальної сфери студентів теоретично обгрунтованими та практично значущими знаннями стосовно батьківства; практичну - формування у студентів ПТНЗ системи практичних умінь та навичок, які сприятимуть у майбутньому ефективній реалізації батьківства через систему взаємодії з дітьми; комунікативну - полягає у навчанні та реалізації ефективних способів спілкування та взаємодії з найближчим оточенням, в тому числі і майбутніми дітьми.

3. Операційний (форми, методи і засоби роботи). 
Форми роботи. Структурно-функціональна модель процесу формування усвідомленого ставлення до батьківства передбачає організацію групової форми роботи, заняття з елементами тренінгу.

Методи роботи. Програма соціально-педагогічної підтримки процесу формування усвідомленого ставлення до батьківства у студентів ПТНЗ передбачає використання елементів арт-терапії та елементів казкотерапії. Методами роботи в рамках даної моделі виступають міні-лекції, інформаційні повідомлення, рольові та інтерактивні ігри, групові дискусії, мозковий штурм.

Засоби роботи - це використання візуальних (мультимедіа-проектор) та друкованих (картки для складання таблиць, роздатковий матеріал) засобів.

4. Результативний (критерії сформованості усвідомленого ставлення до батьківства: гносеологічний - система теоретичних знань; діяльнісний - сформовані уміння і навички, необхідні для ефективної реалізації батьківської ролі; аксіологічний ціннісне ставлення до батьківства, його місце у ієрархії цінностей особистості; акмеологічний - сформовані особистісні якості студента, які становлять підгрунтя батьківської зрілості).

Програма соціально-педагогічної підтримки процесу формування усвідомленого ставлення до батьківства у студентів професійно-технічних навчальних закладів «Світ батьківства: від хаосу до гармонії» була реалізована в умовах професійно-технічних навчальних закладів, включала 10 сесій, кожна 3 яких тривала 120 хвилин.

Практична реалізація даної програми серед дівчат, студенток ПТНЗ, сприяла усвідомленню ними сутності батьківства та материнства, ролі батьків у повноцінному вихованні особистості дитини, а також формуванню позитивної мотивації до реалізації ролі матері у майбутньому. У процесі роботи важливим постало формування у студенток особистісних якостей, які становлять підгрунтя батьківської зрілості. Окрім того, розглядалися й питання вагітності як важливого етапу розвитку майбутнього малюка, були запропоновані вправи задля формування умінь гармонійної взаємодії 3 дитиною на цьому етапі. Беззаперечну цінність мала i зустріч 3 педіатром, який ознайомив дівчат із психологією новонароджених та особливостями догляду за ними. Окрема сесія була присвячена особливостям віку дитини, метою якої було сприяння 
формуванню в учасників системи знань щодо психологічних особливостей дітей на різних вікових етапах, а також умінь щодо ефективної взаємодії 3 ними. Були розглянуті питання виховання дитини та особливості спілкування з нею, створювалися умови задля формування та засвоєння ефективних шляхів взаємодії з дитиною у майбутньому. Проведення сесії «Емоційний світ дитини» сприяло усвідомленню учасниками цінності емоційного світу дитини, формуванню умінь розпізнавати та адекватно реагувати на дитячі емоції. А проведення завершальної сесії дозволило усвідомити дівчатам власний життєвий шлях та місце материнства у ньому.

У процесі роботи дівчата виявили неабиякий інтерес до даної проблеми. Активна участь, емоційне занурення, різноманітність запитань, які потребували відповідей, свідчили про прагнення учасників зануритися у світ батьківства, зокрема і материнства, і пізнати усі його аспекти.

Висновки. Таким чином, впровадження та реалізація структурно-функціональної моделі процесу формування усвідомленого ставлення до батьківства закладе фундамент у якісній підготовці студентів професійно-технічних навчальних закладів до сімейного життя та усвідомленого ставлення до власного батьківства.

\section{References}

1. Kanishevska L.V. Formuvannia tsinnostei simeinoho zhyttia u starshoklasnykiv zahalnoosvitnikh shkil-internativ [Formation of family values in senior pupils in generaleducation boarding schools]. Teoretyko-metodychni problemy vykhovannia ditei ta uchnivskoi molodi : zb. nauk. pr. Kirovohrad: Imeks-LTD, 2014. Vol. 18, Issue 1. P. 297-305.

2. Karpenko O. H. Simia yak subiekt i obiekt diialnosti sotsialnoho pratsivnyka. [Family as a subject and object of the social worker's activity]. Problemy pedahohichnykh tekhnolohii. 2004. No. 1(26). P.176-183.

3. Muhina V.S. Vozrastnaya psihologiya: fenomenologiya razvitiya, detstvo, otrochestvo: uchebnik dlya stud. vuzov [Age psychology: phenomenology of development, childhood, adolescence]. Moskva: Izdatelskiy tsentr «Akademiya», 1999. 456 p.

4. Ovcharova R.V. Psihologicheskiy analiz osobennostey formirovaniya osoznannogo roditelstva $v$ molodoy semye [Psychological analysis of the peculiarities of the formation of conscious parenthood in a young family]. Vestnik instituta semyi: Periodicheskiy nauchnoprakticheskiy zhurnal. Vol. 1. Ekaterinburg: UrGI, 2008. P. 45-50.

5. Petko L.V. Vykhovnyi potentsial metodu sytuatsiinoho analizu («Case study» method) u formuvanni profesiino oriientovanoho inshomovnoho navchalnoho seredovyshcha $v$ umovakh universytetu [Educational potential of the "Case study» method for the forming of the professionally oriented foreign language teaching environment in the conditions of 
university]. Naukovyi chasopys NPU imeni M.D.Drahomanova. Seriia 17. Teoriia i praktyka navchannia ta vykhovannia : zb. nauk. pr. ; za red. akademika V.I.Bondaria. Kyiv: Vyd-vo NPU imeni M.P.Drahomanova, 2015. Issue 27. P. 133-140.

URI http://enpuir.npu.edu.ua/handle/123456789/9455

6. Petko L.V. Realizatsiia moralno-suspilnoi problematyky u formuvanni profesiino oriientovanoho inshomovnoho navchalnoho seredovyshcha $v$ umovakh universytetu [Implementation of the moral and social problems in formation of professionally oriented foreign language learning environment in conditions of university]. Naukovyi chasopys NPU imeni M.D.Drahomanova. Seriia 5. Pedahohichni nauky: realii ta perspektyvy: zb. nauk. pr. ; za red. akademika V.I.Bondaria. Kyiv: Vyd-vo NPU imeni M.P.Drahomanova, 2016. Issue 55. P. $166-173$.

7. Pet'ko L.V. U poshukakh formuly kokhannia studentamy u protsesi formuvannia profesiino oriientovanoho inshomovnoho navchalnoho seredovyshcha $v$ umovakh universytetu [The formula for finding love by students in the process of professionally oriented foreign language teaching environment formation in terms of university]. Naukovi zapysky. Serija "Psyhologo-pedagogichni nauky" (Nizhyns'kyj derzhavnyj universytet imeni Mykoly Gogolja) / za zag. red. prof. Je.I.Kovalenko. Nizhyn : NDU im. M. Gogolja, 2015. No. 4. P. $178-185$.

8. Pet'ko L.V. Formation of professionally oriented foreign language teaching environment in conditions of university and upbringing of moral and ethical values (on illustration of the phenomenon «honesty» and «lie»). Intellectual Archive. 2016. Volume 5. No. 1 (January). Toronto : Shiny Word Corp., Canada. PP. 98-111.

Translation of the Title, Abstract and References to the Author's Language

\section{УДК 377.013.42:316.36-055.52}

Федюшкіна Катерина. Практичні аспекти процесу формування усвідомленого ставлення до батьківства в умовах професійно-технічних навчальних закладів

У статті висвітлено причини знецінення у сучасному українському суспільстві морально-духовної сутності батьківства, зазначені протиріччя даної проблеми, які визначають актуальність наукового дослідження. Наведені прояви кризи батьківства. Обгрунтовано необхідність формування усвідомленого ставлення до батьківства у молоді. Представлено структурно-функціональну модель процесу формування усвідомленого ставлення до батьківства у студентів професійно-технічних навчальних закладів. Розкрито практичні аспекти даного процесу, а також визначено досягнуті студентами результати.

Ключові слова: батьківство, материнство, усвідомлене ставлення до батьківства, студенти професійно-технічних навчальних закладів.

\section{Література}

1. Канішевська Л.В. Формування цінностей сімейного життя у старшокласників загальноосвітніх шкіл-інтернатів // Теоретико-методичні проблеми виховання дітей та 
учнівської молоді : зб. наук. пр. Кіровоград: Імекс-ЛТД, 2014. Вип. 18, Кн. 1. С. 297305.

2. Карпенко О. Г. Сім'я як суб'єкт і об'єкт діяльності соціального працівника. Проблеми педагогічних технологій. 2004. № 1(26). С.176-183.

3. Мухина В.С. Возрастная психология: феноменология развития, детство, отрочество: учебник для студ. вузов. Москва: Издательский центр «Академия», 1999. $456 \mathrm{c}$.

4. Овчарова Р.В. Психологический анализ особенностей формирования осознанного родительства в молодой семье. Вестник института семьи: периодический научн.-практ. журнал. Вып. 1. Екатеринбург: УрГИ, 2008. С. 45-50.

5. Петько Л.В. Виховний потенціал методу ситуаційного аналізу («Case study» method) у формуванні професійно орієнтованого іншомовного навчального середовища в умовах університету. Науковий часопис НПУ імені М.Д.Драгоманова. Серія 17. Теорія і практика навчання та виховання: зб. наук. пр. ; за ред. академіка В.І.Бондаря. Київ: Вид-во НПУ імені М.П.Драгоманова, 2015. Вип. 27. С. 133-140.

6. Петько Л.В. Реалізація морально-суспільної проблематики у формуванні професійно орієнтованого іншомовного навчального середовища в умовах університету. Науковий часопис Національного педагогічного університету імені М. П. Драгоманова. Серія 5: Педагогічні науки: реалії та перспективи: зб. наук. праць. - Київ : Вид-во НПУ ім. М. П. Драгоманова, 2016. Вип. 55. С. 166-173.

7. Петько Л.В. У пошуках формули кохання студентами у процесі формування професійно орієнтованого іншомовного навчального середовища в умовах університету. Наукові записки. Серія "Психолого-педагогічні науки" (Ніжинський державний університет імені Миколи Гоголя) / за заг. ред. проф. С.І.Коваленко. Ніжин : НДУ ім. М. Гоголя, 2015. № 4. С. 178-185.

8. Pet'ko L.V. Formation of professionally oriented foreign language teaching environment in conditions of university and upbringing of moral and ethical values (on illustration of the phenomenon «honesty» and «lie»). Intellectual Archive. 2016. Volume 5. No. 1 (January). Toronto: Shiny Word Corp., Canada. PP. 98-111. 